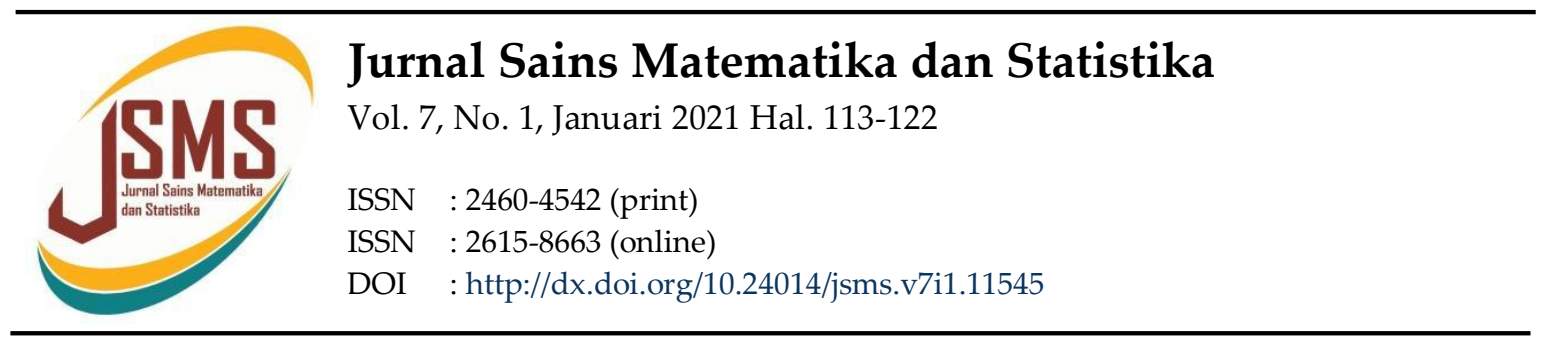

\title{
Optimallisasi Tingkat Produksi Pada Model Sumber Energi Terbarukan
}

\author{
Nilwan Andiraja', Qurati A 'yun'², Pitnelly ${ }^{3}$ \\ 1,2 Prodi Matematika, UIN Sultan Syarif Kasim Riau, ${ }^{3}$ MAN 1 Muaro Bungo \\ Jl. HR. Soebrantas No. 155 Simpang Baru, Panam, Pekanbaru, 28293 \\ Email: nilwanandiraja@uin-suska.ac.id', quatiayun2@gmail.com², pitnellymalik@gmail.com³ \\ ${ }^{*}$ Korespondensi penulis : nilwanandiraja@uin-suska.ac.id
}

\begin{abstract}
Abstrak
Artikel ini membahas tentang model tingkat produksi sumber energi terbarukan. Pada artikel ini diselesaikan permasalahan tingkat produksi sumber energi terbarukan menggunakan kendali optimall. Dengan menggunakan persamaan dinamik dan fungsi tujuan, maka dapat dibentuk persamaan Hamilton dan Lagrange, dan kemudian dapat dibentuk persamaan differensial orde dua untuk mendapatkan persamaan tingkat produksi sumber energi terbarukan yang optimall. Berdasarkan simulasi yang dilakukan dengan diberikan nilai parameter usaha pengembangan energi dan nilai parameter dampak positif pada produksi, maka diperoleh tingkat kapasitas produksi energi terbarukan dapat mengalami kenaikan, penurunan atau berfluktuasi.
\end{abstract}

Kata Kunci: Kendali optimall, sumber energi, tingkat produksi

\begin{abstract}
This article discussed about production level model of renewable energi source. In this article was resolved the problem of the production level of renewable energy source using the optimall control. With using the dynamic equation and objective function, it could be made The Hamilton and Lagrange equation, and then could be made the second order differential equations to acquiring the equation of the production level of renewable energy. Based on the simulation, with given the value of energi development effort parameters and the value of impact positive parameter, it obtained the capacity of the production level of renewable energy increase, decrease, or fluctuation.
\end{abstract}

Keywords: Energi Source, Optimall Control, Production Levels..

\section{Pendahuluan}


Energi merupakan kebutuhan penting bagi manusia. Kebutuhan energi di Indonesia terus meningkat karena pertambahan penduduk, pertumbuhan ekonomi dan pola konsumsi energi itu sendiri yang senantiasa meningkat. Menurut [4], bahan bakar fosil yang selama ini merupakan sumber energi utama ketersediaannya sangat terbatas dan mulai menipis. Hal ini disebabkan bahan bakar fosil merupakan sumber energi tidak terbarukan, yang berarti sumber energi tersebut akan habis dalam jangka waktu tertentu. Jika sumber energi tidak terbarukan habis, maka akan berdampak buruk di seluruh sektor kehidupan, mulai dari rumah tangga, UMKM, transportasi bahkan industry akan berhenti. Oleh karena itu, maka diperlukan suatu tindakan untuk menjamin ketersediaan energi dimasa depan. Salah satu usaha untuk mengatasinya melalui energi alternatif. Energi alternatif merupakan solusi untuk meningkatkan peran energi terbarukan dalam rangka menjamin keamanan pasokan energi untuk memenuhi kebutuhan energi yang semakin meningkat secara keberlanjutan. Walaupun energi terbarukan merupakan solusi energi alternative yang dapat diperbarharui dalam arti jika habis dapat diproduksi ulang, tapi tetap energi terbarukan perlu dikendalikan agar produksi energi terbarukan dapat optimall.

Selanjutnya, untuk meningkatkan dan mengendalikan peran energi alternatif, maka kita perlu melakukan pengendalian yang optimall. Pengendalian tersebut dapat dilakukan dengan mengaplikasikan kendali optimall. Secara teoritis, bentuk pengendalian dengan menggunakan kendali optimall dapat kita lihat pada penelitian terdahulu. Penelitian [2], merupakan penelitian yang telah membahas aplikasi kendali optimall pada permasalahan ketersediaan energi. Pada penelitian tersebut didapat tingkat produksi optimall dan waktu yang dibutuhkan untuk mencapai tingkat produksi yang optimall. Persamaan yang digunakan pada penelitian tersebut adalah persamaan dinamis dan persamaan differensial tidak linear. Adapun persamaan tersebut dengan tingkat produksi pada waktu $t$ yang diselesaikan menggunakan prinsip minimum pontryagin. Berdasarkan penelitian [2], penulis tertarik untuk mengembangkan penelitian tersebut, untuk penentuan tingkat produksi dalam model sumber energi dengan merubah prinsip minimum pontryagin di penelitian [2] dan menggantinya dengan persamaan diferensial orde dua. Adapun penelitain yang lain, pada [2] telah dibahas tentang beberapa potensi energi terbarukan yang potensial untuk Indonesia. Energi-energi potensial tersebut merupakan energy yang dapat dikembangkan di Indonesia seperti panas bumi, energy air dan angin, nuklir dan sebagainya. Tapi pada penelitian [2] tidak memberikan persamaan dinamik yang diperlukan untuk pengembangan energy alternatif tersebut. Kemudian pada penelitian [5], juga telah dibahas tentang manajemen energy terbarukan berupa cell hybrid, tapi pada penelitian ini menggunakan metode yang sama dengan [2], menggunakan prinsip minimum pontryagin. Pada penelitian [5] belum menggunakan persamaan Lagrange. Selanjutnya, artikel ini membahas hanya untuk kasus model sumber energi terbarukan.

\section{Metode Penelitian}

\subsection{Landasan Teori}

\subsubsection{Masalah Umum Kendali Optimall Waktu Kontinu}


Pada bagian ini dibahas masalah umum kendali optimall waktu kontinu untuk persamaan diferensial dinamik untuk waktu $t$. Menurut [2], bentuk umum persoalan kendali optimall, pertama diberikan persamaan differensial dinamik yaitu,

$$
\dot{x}(t)=f(x(t), u(t), t)
$$

dengan $x(t) \in R^{n}$ adalah vektor state dan $u(t) \in R^{m}$ adalah fungsi kendali. Disamping fungsi defferensial dinamik, juga terdapat fungsi tujuan, yaitu

$$
J=\frac{1}{2} \int_{t_{0}}^{t_{1}} L(x, u, t) d t
$$

menurut [5], fungsi tujuan yang diberikan merupakan fungsi tujuan berbentuk kuadratik, dengan $L(x, u, t)$ merupakan weighting function (fungsi yang menggambarkan usaha yang diperlukan) yang bergantung kepada waktu $\left[t_{0}, t_{1}\right]$.

Selanjutnya, menurut [7] untuk mencari solusi masalah kendali optimall waktu kontinu maka dibentuk persamaan Hamilton dan persamaan Lagrange, yang digunakan untuk menentukan kendali optimal. Kendali optimall bisa disebut sebagai titik ekstrim yang mengoptimallkan persamaan differensial dinamik atau fungsi tujuan. Karena menurut [6] titik ekstrim merupakan titik yang memaksimalkan atau meminimalkan nilai suatu fungsi.

\subsubsection{Model Sistem Dinamik Tingkat Produksi Sumber Energi Terbarukan}

Sistem dinamik dari permasalahan energi terbarukan merupakan model matematika berdasarkan pada model Lotka-Voltera. Bentuk model tersebut dinyatakan dalam bentuk persamaan differensial tak linear. Berdasarkan [2] diketahui model matematika dari sistem dinamik sumber energi terbarukan adalah sebagai berikut:

$$
\dot{x}=\alpha x_{1}-\beta x_{1} x_{2} \quad t \in\left[t_{0}, t_{f}\right]
$$

Dimana,

$x_{1}$ : Tingkat kapasitas produksi energi terbarukan pada waktu $t$

$\alpha$ : Persentase tingkat pertumbuhan dalam produksi sumber energi terbarukan

$\beta$ : Konstanta positif yang mempersentasikan dampak yang berpengaruh pada produksi energi terbarukan akibat adanya persaingan dengan tingkat produksi sumber energi tidak terbarukan,

$x_{2}$ : Tingkat kapasitas produksi energi tidak terbarukan pada waktu $t$

Fungsi tujuan dari model energi yaitu sebagai berikut :

$$
J=\frac{1}{2} \int_{t_{0}}^{t_{1}}\left\{q_{1} u_{1}^{2}+q_{2} u_{2}^{2}\right\} d t
$$

Dengan

$u_{1} \quad$ : Kendali tingkat produksi sumber energi terbarukan

$u_{2} \quad$ : Kendali tingkat produksi sumber energi tidak terbarukan

$q_{1}$ : Parameter usaha pengembangan energi dalam hal investasi modal, pemeliharaan, dan biaya insfrastruktur untuk sumber energi terbarukan

$q_{2}$ : Parameter usaha pengembangan energi dalam hal investasi modal, pemeliharaan, dan biaya insfrastruktur untuk sumber energi tidak terbarukan

\subsection{Metode/Metodologi Penelitian}


Artikel ini membahas tingkat produksi untuk energi terbarukan, adapun langkahlangkah yang dilakukan dalam artikel ini sebagai berikut :

1. Diketahui persamaan diferensial dinamik pada Persamaan (1) dan fungsi tujuan pada Persamaan (2). Persamaan (1) dilakukan penyesuaian symbol untuk persoalan satu kendali.

2. Dibentuk persamaan Hamilton dan persamaan Lagrange berdasarkan diferensial dinamik dan fungsi tujuan pada langkah nomor 1.

3. Selanjutnya setelah diperoleh persamaan Hamilton dan persamaan Lagrange dibentuk beberapa persamaan, yaitu

$$
H_{u_{1}}=0, L_{x}=-\lambda \text { dan } L_{u_{1}}=0
$$

yang diperlukan untuk mendapatkan kondisi optimall untuk tingkat produksi sumber energi terbarukan.

4. Dari $H_{u_{1}}=0$ pada nomor 3 didapatkan fungsi kendali yaitu tingkat produksi $u_{1}^{*}(t)$.

5. Dari $L_{x}=-\dot{\lambda}$ dan $L_{u_{1}}=0$ pada nomor 3 didapatlah $-\dot{\lambda}$.

6. Kendali $u_{1}^{*}(t)$ dari langkah nomor 4 disubtitusikan ke persamaan diferensial dinamik pada langkah nomor 1 .

7. Kemudian dibentuk turunan kedua dari persamaan diferensial dinamik pada nomor 6.

8. Dicari solusi turunan kedua untuk persamaan pada langkah nomor 7, yang merupakan solusi untuk tingkat produksi optimall.

9. Selanjutnya diaplikasikan solusi tingkat produksi dalam langkah nomor 7 dengan menggunakan beberapa nilai numerik.

\section{Hasil dan Pembahasan}

\subsection{Kendali Optimall pada Masalah Sumber Energi Terbarukan}

Menurut [2], persamaan diferensial model energi diperoleh dalam dua bentuk persamaan diferensial yaitu untuk energi terbarukan dan energi tidak terbarukan. Pada artikel ini dibahas hanya untuk energi terbarukan, sehingga hanya akan dipakai satu persamaan diferensial dari [2]. Selanjutnya, dengan asumsi untuk energi tidak terbarukan menjadi konstanta dan pada artikel ini hanya akan menentukan satu kendali yaitu untuk energi terbarukan. Maka, perlu dibentuk persamaan diferensial untuk energi terbarukan yaitu

$$
\dot{x}=\alpha u_{1}-\beta x \mu \quad t \in\left[t_{0}, t_{f}\right]
$$

Berdasarkan Persamaan $\dot{x}=\alpha u_{1}-\beta x \mu$ dan Persamaan (2) dibentuk Persamaan Hamilton dan persamaan Lagrange, sebagai berikut:

$$
H=\frac{1}{2}\left[q_{1} u_{1}^{2}+q_{2} u_{2}^{2}\right]+\lambda \alpha u_{1}-\lambda \beta x \mu
$$

dan persamaan Lagrange adalah sebagai berikut:

$$
L=\frac{1}{2}\left[q_{1} u_{1}^{2}+q_{2} u_{2}^{2}\right]+\lambda \alpha u_{1}-\lambda \beta x \mu-\mu \alpha u_{1}+\beta x \mu^{2}
$$

Selanjutnya, dari Persamaan (3) dan (4), dibentuk persamaan-persamaan yaitu,

$$
\begin{aligned}
H_{u_{1}} & =0 \\
L_{x} & =-\dot{\lambda} \\
L_{u_{1}} & =0
\end{aligned}
$$


Selanjutnya berdasarkan Persamaan (5) dan Persamaan (3) maka didapat

$$
u_{1}^{*}(t)=-\frac{\lambda \alpha}{q_{1}}
$$

Dan berdasarkan Persamaan (6) dan Persamaan (4) didapat

$$
\dot{\lambda}=\lambda \mu \beta-\mu^{2} \beta \text {. }
$$

Sehingga berdasarkan Persamaan (7) dan Persamaan (4) didapat

$$
(\lambda \alpha-\alpha \mu)=-q_{1} u_{1}
$$

Dengan mensubtitusikan Persamaan (8) ke Persamaan diferensial dinamik (11) maka diperoleh

$$
\dot{x}=-\frac{\lambda \alpha^{2}}{q_{1}}-\beta x \mu
$$

Dengan menurunkan Persamaan (11) diperoleh

$$
\ddot{x}=-\frac{\dot{\lambda} \alpha^{2}}{q_{1}}-\beta x \dot{\mu}-\beta \dot{x} \mu
$$

Dengan mensubtitusikan Persamaan (9) dan Persamaan (11) ke Persamaan (12) maka diperoleh

$$
\ddot{x}=-\frac{(\lambda \alpha-\alpha \mu) \beta \alpha \mu}{q_{1}}-\beta x \dot{\mu}+\frac{\lambda \beta \alpha^{2} \mu}{q_{1}}+\beta^{2} x \mu^{2}
$$

Dengan disubtitusikan Persamaan (10) maka diperoleh

$$
\ddot{x}=-\frac{\left(-q_{1} u_{1}\right) \beta \alpha \mu}{q_{1}}-\beta x \dot{\mu}+\frac{\lambda \beta \alpha^{2} \mu}{q_{1}}+\beta^{2} x \mu^{2}
$$

Dengan menggunakan Persamaan (16) maka diperoleh sebagai berikut:

$$
\ddot{x}+\left(\dot{\mu}-\beta \mu^{2}\right) \beta x=0
$$

Selanjutnya, akan ditentukan solusi dari Persamaan (15), untuk mendapatkan tingkat produksi yang optimall $(x(t))$ pada model sumber energi terbarukan. Solusi Persamaan (15) akan dibuat dalam dua kasus.

\section{a. Kasus $\mu$ adalah konstanta}

Persamaan (15) merupakan persamaan diferensial orde dua homogen, maka ditentukan penyelesaian umum persamaan homogen

$$
\ddot{x}-\beta^{2} \mu^{2} x=0
$$

Langkah pertama yang dilakukan dalam penyelesaian Persamaan (16) yaitu menentukan terlebih dahulu penyelesaian umum persamaan homogen sehingga akan diperoleh persamaan karakteristiknya sebagai beriku:

$$
r^{2}-\beta^{2} \mu^{2}=0
$$

dan akar-akar persamaan yang diperoleh

$$
r_{1}=\beta \mu=r
$$

Dan

$$
r_{2}=-\beta \mu=-r
$$

Sehingga solusi dari Persamaan (17) adalah

$$
x(t)=c_{1} e^{r t}+c_{2} e^{-r t}
$$

dengan : $c_{1}=\frac{M e^{-r t_{f}}}{\left(e^{r t_{0}}\right)\left(e^{-r t} f\right)-\left(e^{-r t_{0}}\right)\left(e^{r t_{f}}\right)}$ dan, $c_{1}=\frac{-M e^{r t_{f}}}{\left(e^{r t_{0}}\right)\left(e^{-r t_{f}}\right)-\left(e^{-r t_{0}}\right)\left(e^{r t_{f}}\right)}$

\section{b. Kasus $\mu$ merupakan bentuk linier dalam $t$}

Jika $\mu$ pada Persamaan (15) merupakan bentuk linier dalam $t$, maka dapat ditulis sebagai berikut:

$$
\ddot{x}+\left(\dot{\mu}-\beta \mu^{2}\right) \beta x=0
$$


sehingga akan diperoleh persamaan karakteristiknya sebagai berikut:

$$
r^{2}+\left(\dot{\mu}-\beta \mu^{2}\right) \beta=0
$$

dengan akar-akar persamaan yang diperoleh sebagai berikut:

$$
r_{1,2}= \pm k
$$

Sehingga solusi dari Persamaan (19) yang merupakan tingkat produksi energi terbarukan, untuk kasus kedua adalah

$$
x(t)=\left(c_{1} \cos k t+c_{1} \sin k t\right)
$$

dengan,

$$
c_{1}=\frac{M \sin \left(r t_{f}\right)}{\left(\cos \left(r t_{0}\right) \sin \left(r t_{f}\right)\right)-\left(\sin \left(r t_{0}\right) \cos \left(r t_{f}\right)\right)}
$$

dan,

$$
c_{2}=\frac{-M \cos \left(r t_{f}\right)}{\left(\cos \left(r t_{0}\right) \sin \left(r t_{f}\right)\right)-\left(\sin \left(r t_{0}\right) \cos \left(r t_{f}\right)\right)}
$$

\subsection{Simulasi Numerik}

Berdasarkan penyelesaian untuk dua kasus tersebut maka akan diberikan beberapa contoh. Dimana pada contoh simulasi numerik ini sebagaian besar nilai parameter diambil dari artikel [2]. Pada artikel [2] telah dibahas simulasi numerik untuk tingkat produksi energi terbarukan dengan berbagai nilai parameter dengan prinsip maksimum pontryagin. Diperoleh hasil terdapat tingkat produksi meningkat dan terdapat tingkat produksi menurun. Adapun pada artikel ini, dengan mengambil beberapa nilai parameter yang sama dengan artikel [2], akan disimulasikan dengan menggunakan hasil yang diperoleh pada artikel ini.

Contoh 1 :

Berdasarkan [2] diketahui nilai parameter yang digunakan untuk memproduksi sumber energi terbarukan. Dalam hal ini, energi yang dihasilkan berupa pembangkit listrik dengan satuan MW (Mega Watt). Adapun nilai input parameternya antara lain: $q_{1}=2, q_{2} u_{2}^{2}=2, \alpha=0,05, \mu=3$, sedangkan nilai parameter komputasi yang digunakan adalah $\beta=0,2$. Tentukan nilai optimall tingkat produksi sumber energi $(x(t))$ dan analisa kestabilannya pada saat $t \in[0,10]$ dengan tingkat persediaan awal sebesar 15 .

Penyelesaian:

Berdasarkan Persamaan (9) dan parameter yang diketahui dari soal maka akan diperoleh Persamaan diferensial dinamik sebagai berikut:

$$
\dot{x}=\alpha u_{1}-\beta x \mu=0,05 u_{1}-0,6 x
$$

Dengan fungsi tujuan yaitu:

$$
J=\frac{1}{2} \int_{t_{0}}^{t_{1}}\left\{2 u_{1}^{2}+2\right\} d t
$$

Dengan menggunakan kasus pertama maka diperoleh persamaan karakteristik sebagai berikut:

$$
r_{1}=\beta \mu=0,6
$$

Selanjutnya mencari nilai $c_{1}$ dan $c_{2}$ sebagai berikut:

$$
c_{1}=\frac{M e^{-r t_{f}}}{\left(e^{r t_{0}}\right)\left(e^{-r t_{f}}\right)-\left(e^{-r t_{0}}\right)\left(e^{r t_{f}}\right)}=0,253840239
$$


Selanjutnya mencari nilai $c_{2}$ sebagai berikut:

$$
c_{1}=\frac{-M e^{r t_{f}}}{\left(e^{r t_{0}}\right)\left(e^{-r t_{f}}\right)-\left(e^{-r t_{0}}\right)\left(e^{r t_{f}}\right)}=-0,798476142
$$

Kemudian diperoleh tingkat produksi sumber energi terbarukan yang optimall sebagai berikut:

$$
x(t)=c_{1} e^{r t}+c_{2} e^{-r t}=(0,2538402391) e^{0,6 t}-(0,798476142) e^{-0,6 t}
$$

Nilai solusi persamaan $x(t)$ untuk $t \rightarrow 10$ yang diperoleh terlihat pada grafik berikut:

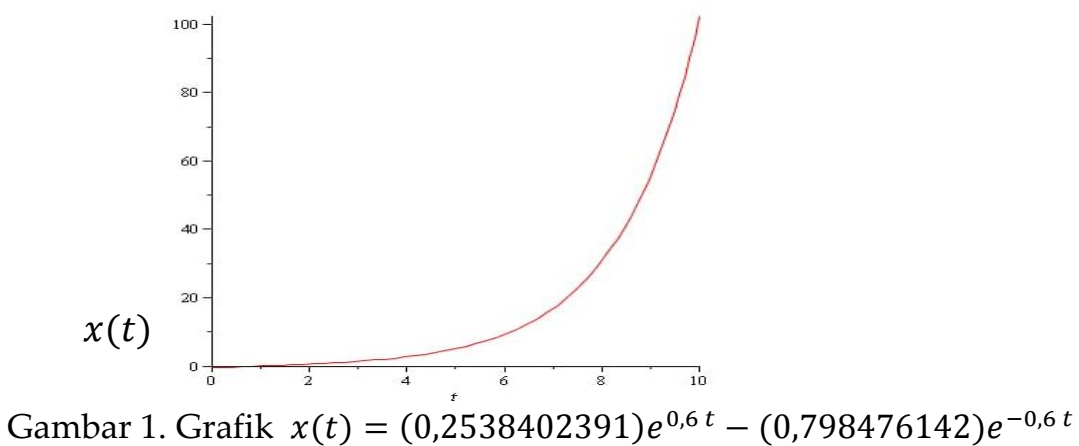

Berdasarkan Gambar 1, dapat dilihat bahwa untuk $t \rightarrow 10$ diperoleh nilai optimall tingkat produksi $x(t)$ meningkat stabil.

Contoh 2 :

Berdasarkan Contoh 1 Tentukan nilai optimall tingkat produksi sumber energi $x(t)$ dan analisa kestabilannya pada saat $t \in[0,10]$ dengan tingkat persediaan awal sebesar 20. Jika diberikan $q_{1}=2, q_{2} u_{2}^{2}=2, \alpha=0,05, \mu=5, \beta=0,5$

Penyelesaian:

Berdasarkan Contoh 2 dan parameter yang diketahui dari soal, maka akan diperoleh Persamaan diferensial dinamik dan fungsi tujuan, sebagai berikut:

$$
\begin{aligned}
& \dot{x}=0,05 u_{1}-0,5 x \\
& J=\frac{1}{2} \int_{t_{0}}^{t_{1}}\left\{2 u_{1}^{2}+2\right\} d t
\end{aligned}
$$

Dengan menggunakan kasus pertama maka diperoleh persamaan karakteristik sebagai berikut:

$$
r=0,5, \quad c_{1}=-0,2263252218, \quad c_{1}=33,58964115
$$

Kemudian diperoleh tingkat produksi sumber energi terbarukan yang optimall sebagai berikut:

$$
x(t)=(-0,2263252218) e^{0,5 t}-(33,58964115) e^{-0,5 t}
$$

Nilai solusi persamaan $x(t)$ untuk $t \rightarrow 10$ yang diperoleh terlihat pada grafik berikut:

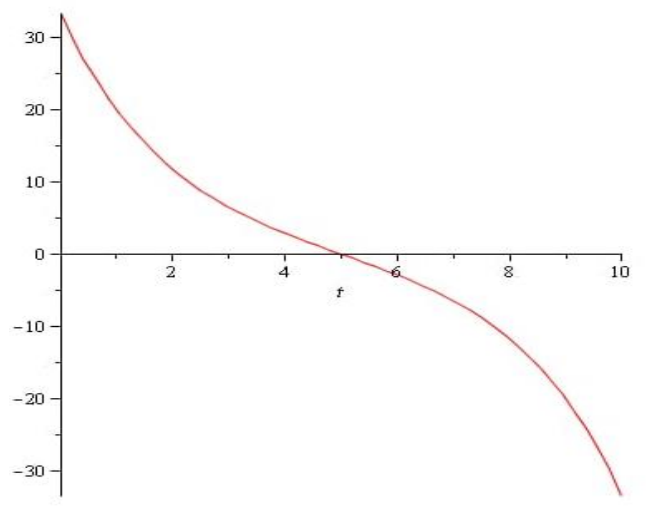


Berdassarkan Gambar 2 di atas dapat dilihat bahwa untuk $t \rightarrow 10$ diperoleh nilai optimall tingkat produksi $x(t)$ mengalami penurunan. Hal ini terjadi karena, ketika tingkat pertumbuhan energi terbarukan konstan seperti pada contoh 1, tetapi tingkat produksi energi tidak terbarukan meningkat. Ditambah persaingan energi terbarukan dengan tidak terbarukan yang besar menambah kondisi tingkat produksi energi terbarukan terus turun bahkan mencapai nilai negatif. Nilai negatif menunjukkan produksi dari waktu ke waktu terus mengalami penurunan.

\section{Contoh 3 :}

Berdasarkan Contoh 1 maka diberikan dan $=0,05, \mu=2 t, \beta=0,1, q_{1}=3, q_{2} u_{2}^{2}=4$. Tentukan nilai optimall tingkat produksi sumber energi $x(t)$ dan analisa kestabilannya pada saat $t \in[0,10]$ dengan tingkat persediaan awal sebesar 10 .

Penyelesaian :

Berdasarkan Contoh 3 dan parameter yang diketahui dari soal maka akan diperoleh Persamaan (1) sebagai berikut:

$$
\dot{x}=0,05 u_{1}-0,2 t x
$$

Diketahui persamaan fungsi tujuan yaitu:

$$
J=\frac{1}{2} \int_{t_{0}}^{t_{1}}\left\{3 u_{1}^{2}+4\right\} d t
$$

Dengan menggunakan kasus kedua maka diperoleh persamaan karakteristik sebagai berikut:

$$
k=\frac{1}{2} \sqrt{0,8+0,16 t^{2}}
$$

Dengan,

$$
\begin{aligned}
c_{1}= & \frac{10 \sin \left(0,475 \sqrt{0,8+0,16 t^{2}}\right)}{\left(\cos \left(0,25 \sqrt{0,8+0,16 t^{2}}\right) \sin \left(0,475 \sqrt{0,8+0,16 t^{2}}\right)\right)} \\
& -\left(\sin \left(0,25 \sqrt{0,8+0,16 t^{2}}\right) \cos \left(0,475 \sqrt{0,8+0,16 t^{2}}\right)\right) \\
c_{2}= & 10 \cos \left(0,475 \sqrt{0,8+0,16 t^{2}}\right) \\
& -\left(\cos \left(0,25 \sqrt{0,8+0,16 t^{2}}\right) \sin \left(0,475 \sqrt{0,8+0,16 t^{2}}\right)\right)
\end{aligned}
$$

Maka diperoleh tingkat produksi sumber energi terbarukan yang optimal sebagai berikut: 


$$
\begin{aligned}
x(t) & =\left(\begin{array}{c}
10 \sin \left(0,475 \sqrt{0,8+0,16 t^{2}}\right) \cos \frac{1}{2} \sqrt{0,8+0,16 t^{2}} \\
\left(\cos \left(0,25 \sqrt{0,8+0,16 t^{2}}\right) \sin \left(0,475 \sqrt{0,8+0,16 t^{2}}\right)\right) \\
-\left(\sin \left(0,25 \sqrt{0,8+0,16 t^{2}}\right) \cos \left(0,475 \sqrt{0,8+0,16 t^{2}}\right)\right)
\end{array}\right) \\
& -\left(\begin{array}{c}
\left.\frac{10 \cos \left(0,475 \sqrt{0,8+0,16 t^{2}}\right) \sin \frac{1}{2} \sqrt{0,8+0,16 t^{2}}}{\left(\cos \left(0,25 \sqrt{0,8+0,16 t^{2}}\right) \sin \left(0,475 \sqrt{0,8+0,16 t^{2}}\right)\right.}\right) \\
-\left(\sin \left(0,25 \sqrt{0,8+0,16 t^{2}}\right) \cos \left(0,475 \sqrt{0,8+0,16 t^{2}}\right)\right)
\end{array}\right)
\end{aligned}
$$

Nilai solusi persamaan $x(t)$ untuk $t \rightarrow 10$ yang diperoleh terlihat pada grafik,

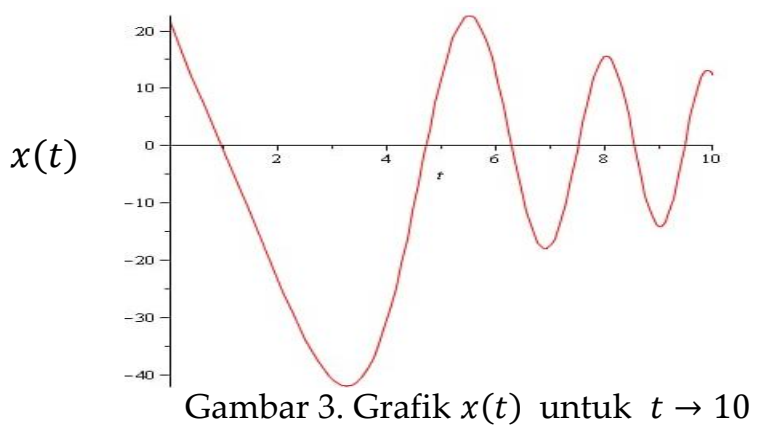

Berdasarkan Gambar 3 tampak bahwa untuk $t \rightarrow 10$ diperoleh tingkat produksi $x(t)$ mengalami kenaikan dan penurunan yang dinamis, dengan semakin menuju waktu $t=10$ selisih kenaikan dan penurunan semakin mengecil. Hal ini karena tingkat produksi energi terbarukan tetap tapi tingkat energi tidak terbarukan mengikuti garis lurus, namun persaingan mengalami penurunan dibandingkan dengan contoh 2 . Hal ini menyebabkan tingkat produksi energi terbarukan masih dapat bersaing walaupun disuatu waktu tingkat produksi menurun, hal ini terjadi karena usaha seperti invertasi modal atau pemeliharaan energi terbarukan lebih kecil dibanding energi tidak terbarukan.

\section{Kesimpulan}

Berdasarkan pembahasan diperoleh kesimpulan. Bahwa berdasarkan persamaan diferensial sistem dinamik untuk kasus tingkat produksi sumber energi terbarukan pada waktu berhingga, diperoleh solusi tingkat produksi untuk model energi terbarukan untuk dua kasus yaitu:

a. Ketika fungsi $\mu$ dalam bentuk konstanta maka akan diperoleh solusi sebagai berikut:

$x(t)=c_{1} e^{r t}+c_{2} e^{-r t}$

dengan nilai $c_{1}$ dan $c_{2}$ yaitu,

$$
\begin{aligned}
& c_{1}=\frac{M e^{-r t_{f}}}{\left(e^{r t_{0}}\right)\left(e^{-r t_{f}}\right)-\left(e^{-r t_{0}}\right)\left(e^{r t_{f}}\right)} \\
& c_{1}=\frac{-M e^{r t_{f}}}{\left(e^{r t_{0}}\right)\left(e^{-r t_{f}}\right)-\left(e^{-r t_{0}}\right)\left(e^{r t_{f}}\right)}
\end{aligned}
$$


b. Jika fungsi $\mu$ merupakan bentuk linier dalam $t$ maka akan diperoleh solusi sebagai berikut:

$x(t)=\left(c_{1} \cos k t+c_{1} \sin k t\right)$

dengan nilai $c_{1}$ dan $c_{2}$ yaitu,

$$
\begin{aligned}
& c_{1}=\frac{M \sin \left(r t_{f}\right)}{\left(\cos \left(r t_{0}\right) \sin \left(r t_{f}\right)\right)-\left(\sin \left(r t_{0}\right) \cos \left(r t_{f}\right)\right)} \\
& c_{2}=\frac{-M \cos \left(r t_{f}\right)}{\left(\cos \left(r t_{0}\right) \sin \left(r t_{f}\right)\right)-\left(\sin \left(r t_{0}\right) \cos \left(r t_{f}\right)\right)}
\end{aligned}
$$

Selanjutnya dari beberapa simulasi numerik, diperoleh bahwa tingkat produksi energi yang terbarukan bergerak dinamis. Tingkat produksi dapat meningkat, menurun dan dinamis naik turun.

\section{Daftar Pustaka}

[1] Al Hakim, Ridlo R, “Model Energi Indonesia, Tinjauan Potensi Energi Terbarukan untuk Ketahanan Energi di Indonesia, “ ANDASIH Jurnal Pengabdian Masyarakat, vol 1 no 1, 2020.

[2] Khoir, Misbahur, Subchan, "Waktu Optimall dalam Diversifikasi Produksi Sumber Energi Terbarukan dan Tidak Terbarukan dengan Menggunakan Prinsip Minimum Pontryagin, "Jurnal Sains dan Seni POMITS, vol. 2, no.1, p. 2337-2520, 2013.

[3] Lewis, Frank L, Optimall Control. 1995.

[4] Muhajjir M, Persamaan Diferensial Biasa dengan MAPLE, 2018.

[5] Song, K., Wang, X., Li, F., Sorrentino, M., \& Zheng, B. "Pontryagin's minimum principle-based real-time energy management strategy for fuel cell hybrid electric vehicle considering both fuel economy and power source durability". Energy, 205, 118064, 2020

[6] Syukri NM, Jusuf, Membangun Kerangka Pikir Energi Terbarukan, 2014.

[7] Ogata, Katsuhiko, Discrete Time Control System, 1995.

[8] Purcell, EJ, Varbeg, D, Kalkulus dan Geometri Analitis, 2005.

[9] Sethi, Suresh P, Thompson GL, Optimall Control Theory Apllications to Management Science and Economics, Second edition. 2005. 